\title{
Warto mieć ład przestrzenny czy opłaca się mieć ład przestrzenny?
}

\author{
Łukasz Samul \\ Uniwersytet Gdański, Wydziat Oceanografii i Geografii, Instytut Geografii \\ E-mail: l.samul.372@studms.ug.edu.pl \\ tutor: dr Krzysztof Kopeć \\ Uniwersytet Gdański, Wydział Oceanografii i Geografii, Instytut Geografii', \\ Zakład Rozwoju Regionalnego
}

Stowa kluczowe: tad przestrzenny, zagospodarowanie przestrzenne, estetyka przestrzeni, reklama w przestrzeni publicznej

Tytuł tego artykułu jest parafrazą cytatu z Władysława Bartoszewskiego. Powiedział on, że "Warto być uczciwym, choć nie zawsze się to opłaca. Opłaca się być nieuczciwym, ale nie warto". W ten dwojaki sposób można też rozpatrywać kwestię ładu przestrzennego, na jednej szali stawiając aspekty moralne, a na drugiej ekonomiczne.

Warto zacząć rozważania od samej definicji ładu przestrzennego. Jest to problem często podejmowany w literaturze, a różni autorzy inaczej wyjaśniają to pojęcie. Według Meyer (2011, s.26) "ład przestrzenny w szerokim ujęciu łączy wszystkie kategorie ładu (ekologicznego, społecznego, gospodarczego, przestrzennego) oznaczając sposób organizacji przestrzennej i funkcjonowania systemu społeczno-ekonomicznego, który realizuje kryteria racjonalności społecznej i umożliwia prawidłowe działanie systemu oraz utrzymanie odpowiedniego stanu środowiska". Ta sama autorka opisuje ład również jako dynamicznie przebiegający proces, którego celem jest osiągnięcie optymalnego stanu zagospodarowania przestrzeni. Z kolei Woźniak (2015, s.169) z jednej strony określa ład przestrzenny jako „nieodłączny atrybut konstytucyjnie gwarantowanego zrównoważonego rozwoju”, "miernik dobra wspólnego". Z drugiej strony jest to też według niego pojęcie niejednoznaczne, które trudno jest obiektywnie odnieść do rzeczywistości. Wiele zróżnicowanych określeń ładu przestrzennego pada również w pracy Kozłowskiego i in. (2016). Nazywa się go tam m.in. złożonym problemem prawnym, ekonomicznym, urbanistycznym, architektonicznym, społecznym, ekologicznym i geograficznym: "uporządkowaną, estetyczną i spójną przestrzenią" czy "syntezą wiedzy o przestrzeni i środowisku życia człowieka, sumą jego doświadczeń i zamierzeń"

\footnotetext{
${ }^{1}$ Obecnie Wydział Nauk Społecznych, Instytut Geografii Społeczno-Ekonomicznej i Gospodarki Przestrzennej
} 
(Kozłowski i in., 2016, 17). Ład przestrzenny został także zdefiniowany w polskim prawie. Według ustawy z dnia 27 marca 2003 r. o planowaniu i zagospodarowaniu przestrzennym (Dz.U. 2003 nr 80 poz. 717) jest to „takie ukształtowanie przestrzeni, które tworzy harmonijną całość oraz uwzględnia w uporządkowanych relacjach wszelkie uwarunkowania i wymagania funkcjonalne, społeczno-gospodarcze, środowiskowe, kulturowe oraz kompozycyjno-estetyczne". Biorąc pod uwagę mnogość i różnorodność definicji funkcjonujących w literaturze przedmiotu ta wpisana do polskiego systemu prawnego jest oszczędna i mało rozbudowana.

Jednak czy w publicznej świadomości w ogóle istnieje pojęcie ładu przestrzennego? Zastanawiając się nad jego wartością czy też opłacalnością trzeba przede wszystkim obrać odpowiednią perspektywę.

Z mojego punktu widzenia zarówno warto, jak i opłaca się mieć ład przestrzenny, ale wydaje mi się, że ogół społeczeństwa ma odmienne zdanie na ten temat, albo tego zdania w ogóle nie posiada. Krajobraz Polski od lat 90-tych XX wieku jest stale degradowany i pogrążany w chaosie kosztem chęci szybkiego zarobku. Z perspektywy krótkoterminowej liberalne podejście do zasad gospodarowania przestrzenią jest korzystne ekonomicznie. Zakłócające ład reklamy są źródłem dochodu dla wielu osób. Powstające w chaosie inwestycje przynoszą często duże zyski inwestorom, a na dodatek często znajdujące się w złych z perspektywy planistycznej miejscach inwestycje mieszkaniowe pozwalają na zakup nieruchomości ludziom, których w innym wypadku nie byłoby na nią stać. Zdecydowanych przeciwników zaburzania ładu przestrzennego, którzy aktywnie temu przeciwdziałają jest niewielu. Największa, neutralna część populacji albo estetyką krajobrazu się w ogóle nie przejmuje, albo ma o niej niewielkie pojęcie. Według wyni- ków badań z 2010 roku 80\% Polaków pozytywnie oceniało ład przestrzenny w miejscu swojego stałego zamieszkania (Komunikat z badań. Polacy o architekturze, 2010). W 2017 roku wartość ta spadła wprawdzie do 70\% (Maciejczak-Kwiatkowska i in., 2018), ale wciąż mowa tu o zdecydowanej większości respondentów, co biorąc pod uwagę polskie realia (ponad 60\% Polaków żyje na terenach poddanych presji bezładu przestrzennego (Chmielewski i in., 2018)) świadczy o nikłej wrażliwości respondentów na chaos przestrzenny. Obrazują to również wyniki badań badających stosunek społeczeństwa do reklam w przestrzeni publicznej. W przeprowadzonym w 2008 roku badaniu 67\% warszawiaków stwierdziło, że lubi oglądać reklamy na mieście (Izba Gospodarcza Reklamy Zewnętrznej, za: Springer, 2013). Z kolei w 2007 roku ponad połowa spośród badanych mieszkańców Rybnika uważała, że reklam w ich mieście jest w sam raz, a na dodatek je upiększają (Nawrocki, 2011).

Gdyby kierować się opinią publiczną, należałoby stwierdzić, że ładu przestrzennego nie warto i nie opłaca się mieć. Jednakże liczne przykłady z literatury naukowej skłaniają do innego spojrzenia na ten problem. Po pierwsze, warto mieć ład przestrzenny. Chęć-Małyszek (2015, 30) stwierdza, że "stan przestrzeni publicznej świadczy o kulturze kraju i poziomie rozwoju estetycznego społeczeństwa". Ta sama autorka stwierdza również, że chaos (np. w postaci wszechobecnych i agresywnych reklam) godzi w harmonię i spokój społeczny. Kwestia harmonii i jej odczuwania przewija się zresztą w wielu opracowaniach naukowych. Nawet jeśli większość społeczeństwa przywykła już do braku ładu przestrzennego to wciąż przywrócenie harmonii na pewno wpłynęłoby pozytywnie na samopoczucie ludzi. Lepiej funkcjonuje się w przyjaznej do oglądania przestrzeni, w której banery reklamowe nie przesłaniają widoku na detale budynków i architekturę miejską, a budynki przedstawiają 
pewną spójność architektoniczną oraz plan urbanistyczny lub ruralistyczny. Reklamy zaśmiecają miasta nie tylko w aspekcie wizualnym, ale także fizycznym. Szczególnie dobrym przykładem mogą być w tym przypadku kampanie wyborcze, których efekty w postaci porozrzucanych po ulicach kartonów, ulotek i banerów można w wielu miejscowościach obserwować przez jeszcze bardzo długi czas po wrzuceniu swojego głosu do urny.

Ład przestrzenny się opłaca. Wiele przykładów pokazuje, że w dłuższej perspektywie czasowej wpływa on pozytywnie na rachunek ekonomiczny. Na jego zaprowadzeniu straciłyby przede wszystkim małe, działające na granicy prawa agencje reklamowe oraz deweloperzy, a zyskałoby wielu mieszkańców miast i lokalnych przedsiębiorców. Estetyka oraz naturalny wygląd miejsca przyciągają bowiem klientów i turystów lepiej niż kiczowate banery. Według Nawrockiego (2011) przestrzeń centralna, a więc będąca domyślnie miejscem koncentracji usług i konsumentów, w śląskich miastach (Katowice, Bielsko-Biała, Rybnik) cechuje się zdecydowanie większym "nasyceniem" przestrzeni nośnikami reklamowymi niż obszary poza centrum. Taki stan rzeczy powtarza się w Polsce w wielu miejscach o podobnym znaczeniu. Twórcy reklamy nie analizują miejsca, w którym zostanie ona umieszczona i nie dostosowują ich do jego rangi (Anioł, 2004). Sytuacja jest z reguły jeszcze gorsza jeśli domyślnym odbiorcą reklamy i klientem lokalnych przedsiębiorców ma być turysta. Powstające wtedy elementy zagospodarowania przestrzeni są najczęściej wykorzystywane w pełni jedynie w okresie sezonu turystycznego, zaś konsekwencje krajobrazowe i funkcjonalne mają charakter stały i często nieodwracalny. Takie działanie prowadzi do powstania przestrzeni "zturystyfikowanej”, charakteryzującej się brakiem poszanowania do wartości krajobrazowych czy historycz- nych. To natomiast może powodować w dalszej perspektywie czasowej odpływ turystów i zmniejszenie przychodów z tego sektora gospodarki (Meyer, 2011).

Z drugiej strony istnieje wiele przykładów pokazujących pozytywny wpływ wysokiej estetyki miejsca na bilans finansowy. Nawet reklama jeśli ma odpowiednią formę i jest dopasowana do otoczenia może wnosić do przestrzeni dodatkowe walory estetyczne (Chęć-Małyszek, 2015; Nawrocki, 2011). W latach 50-tych i 60-tych XX wieku Polska, a w szczególności Warszawa charakteryzowały się dużym wykorzystaniem neonów w przestrzeni publicznej. Wprawdzie w gospodarce socjalistycznej ze względu na ubogość oferty handlowej bezcelowe było jej szczególne reklamowanie, neony zaczęły powstawać na mocy odgórnych decyzji mających na celu nadanie miastom bardziej wielkomiejskiego charakteru. Neony, chociaż przez reklamodawców zostały zapomniane, wciąż cieszą się w Polsce dużą grupą wielbicieli, o czym świadczy chociażby popularność warszawskiego Muzeum Neonów. W obecnych warunkach gospodarczych zastąpienie nimi tandetnych banerów mogłoby być nie tylko elementem kształtowania ładu przestrzennego, ale też magnesem dla klientów.

Dla wspólnego dobra potrzebna jest systemowa walka z nieładem, ale też przede wszystkim edukacja - i to nie tylko dzieci i młodzieży, ale także dorosłych. Szczególną rolę wśród tej drugiej grupy pełnią przedsiębiorcy, ponieważ mają oni znaczący wpływ na kształtowanie przestrzeni. Pozytywne (chociaż póki co niezbyt liczne) efekty tego drugiego rozwiązania od początku minionej dekady zaczynają być widoczne w Gdyni. Powoli zmienia się oblicze śródmieścia będącego handlowo-usługowym centrum miasta. Kluczową rolę odgrywa w tym przypadku działalność we współpracy z Urzędem Miasta 
organizacji Traffic Design. W regularnych cyklach zachęca ona przedsiębiorców do współpracy i projektuje szyldy wpasowujące się w modernistyczną zabudowę dzielnicy. Mimo, że naklejki na szybach odcinające punkty usługowe od promieni słonecznych i chodników wciąż pozostają popularne w wielu branżach i widoczne w krajobrazie polskich miast, to jednak da się zauważyć trend na zastępowanie ich przejrzystymi witrynami z bogatymi wystawami. Pewnym światełkiem w tunelu w tym kontekście może być obowiązująca od 2015 roku tzw. ustawa krajobrazowa'. Pozwala ona samorządom na szczeblu gminnym (w tym samorządom miast na prawach powiatu) na wprowadzanie w życie uchwał umożliwiających realną walkę z chaosem reklamowym. Efekty tych działań widać już m.in. w Gdańsku.

Aspektem gospodarowania przestrzenią, w którym perspektywy są mniej optymistyczne jest pojawianie się w krajobrazie nowych budowli. Obowiązująca w Polsce ustawa o planowaniu i zagospodarowaniu przestrzennym wprowadziła do polskiego prawodawstwa instrument paraplanistyczny w postaci decyzji administracyjnej określającej warunki zabudowy i zagospodarowania przestrzennego wydawanej na obszarach, które nie mają obowiązujących miejscowych planów zagospodarowania przestrzennego (Prus i in., 2015). Obszarów takich jest w Polsce bardzo wiele. Stanowią one chociażby ponad połowę powierzchni Warszawy. Szeroko zakrojone korzystanie z tego instrumentu prawnego i w większości przypadków liberalne interpretowanie przepisów na korzyść inwestorów przyczyniło się do pogłębienia się chaosu przestrzennego w Polsce. Regularnie stosowany jest szereg złych prak-

\footnotetext{
${ }^{1}$ Ustawa z dnia 24 kwietnia 2015 r. o zmianie niektórych ustaw w związku ze wzmocnieniem narzędzi ochrony krajobrazu, Dz.U. 2015 poz. 774

2 Ustawa z dnia 16 kwietnia 2004 r. o ochronie przyrody definiuje oś widokową jako wyobrażalną
}

tyk, takich jak niepoprawne obliczanie wysokości nowych budynków, zła interpretacja obowiązującej linii zabudowy, wyznaczanie niepokrywających się ze stanem rzeczywistym osi widokowych czy ograniczanie konserwatorskiej ochrony zabytków.

Opłaca się zachować ład w planowaniu nowych inwestycji. Przestrzenie bardziej atrakcyjne estetycznie, o czytelnej kompozycji przestrzennej i wyrazistym stylu, w czystym i zdrowym środowisku osiągają znacznie wyższe ceny na rynku nieruchomości. $W$ tych samych regionach działki położone wyżej (a więc z lepszym widokiem) są warte kilkakrotnie więcej (m.in. Roztocze, gmina Wizna). W Warszawie oś widokowa ${ }^{2}$ wyznaczona wzdłuż linii Wisły przełamuje zasadę renty gruntowej $w$ cenach nieruchomości (Chmielewski i in., 2018). Z kolei według badań przeprowadzonych wśród osób związanych z rynkiem nieruchomości ponad 3/4 respondentów uważa, że walory krajobrazowe stanowią co najmniej 10\% wartości nieruchomości (Osikowska i Przetacznik, 2007).

Niekontrolowana, rozproszona rozbudowa jest również związana ze zwiększonym wysiłkiem finansowym dla gmin koniecznym do zapewnienia w nowo zajmowanych lokalizacjach odpowiednich warunków bytowych. Dokonująca się od przełomu XX i XXI w. w Polsce na dużą skalę, a będąca skutkiem procesu rozproszonej suburbanizacji, kolonizacja przedmieść zmniejsza efektywność inwestycji infrastrukturalnych i zwiększa koszty obsługi rozproszonej zabudowy, utrudnia też dostępność usług, zwiększa zużycie energii, wymusza przemieszczenia ludności związane z dojazdami do pracy i miejsc świadczenia usług (Grochowski, 2011). Pie-

prostą kierującą wzrok na charakterystyczne elementy zagospodarowania terenu lub terenów (Dz.U. 2004 nr 92 poz. 880) 
niądze z podatków są w ten sposób przejadane, na wydatki, których przy zachowaniu ładu przestrzennego można było uniknąć.

Powyższe przykłady dowodzą, że ład przestrzenny zarówno warto mieć i opłaca się mieć. Jest on cenną wartością społeczną, psychologiczną i moralną, a jednocześnie jest on opłacalny ekonomicznie. Zmiany w polskim prawie z jednej strony dają nadzieję na poprawę w najbliższej przyszłości estetyki krajobrazu, przede wszystkim w miastach. Z drugiej strony wciąż niestety pogłębia się chaos i bezład w powstawaniu nowych inwestycji, a odwrócenie negatywnych trendów może być bardzo trudne.

\section{Literatura:}

Anioł M., 2004. Reklama w krajobrazie. Architektura krajobrazu, 1-2, 57-62.

Chęć-Małyszek A., 2015. Reklama w sztuce, sztuka w reklamie a przestrzeń publiczna. Teka Komisji Architektury, Urbanistyki i Studiów Krajobrazowych, 11(4), 24-33.

Chmielewski T.J., Śleszyński P., Chmielewski Sz., Kułak A., 2018. Ekologiczne i fizjonomiczne koszty bezładu przestrzennego, Prace Geograficzne nr 264, Warszawa, IGiPZ PAN.

Grochowski M. 2011. Metropolizacja a kształtowanie ładu przestrzennego układów zurbanizowanych. Mazowsze. Studia Regionalne, 6, 167-172.

Komunikat z badań. Polacy o architekturze, 2010. Warszawa, CBOS,

https://www.cbos.pl/SPI-

SKOM.POL/2010/K_134_10.PDF (dostęp: 17.09.2021)

Kozłowski L. i inni, 2016. Ład przestrzenny w województwie kujawsko-pomorskim. Diagnoza z założeniami programu jego kształtowania, Toruń, UMWKP - WNoZi UMK, https://www.kujawsko-pomor- skie.pl/pliki/2017/planowanie/20170320_lad/Lad_przestrzenny.pdf (dostęp: 17.09.2021)

Maciejczak-Kwiatkowska Z., Retko-Bernatowicz M., Wiśniewski R., 2018. W dialogu z otoczeniem? Społeczne postrzeganie przestrzeni publicznej i architektury w Polsce. Raport z badania ilościowego, Warszawa, Narodowe Centrum Kultury, https://nck.pl/upload/2018/11/spoleczne-postrzeganie-architektury_raport.pdf (dostęp: 17.09.2021)

Meyer B., 2011. Turystyka a ład przestrzenny. Wzajemne relacje. Turyzm, 21(1-2), 2532.

Nawrocki T., 2011. Miasta nasze a w nich... Refleksje w wpływie reklamy zewnętrznej na miejską ikonosferę. Acta UniversitatisLodziensis. Folia Sociologica, 36, 121-140.

Osikowska W., Przetacznik, J., 2007. Problemy percepcji i oceny estetycznej krajobrazu Krakowa. Roczniki Geomatyki, t. V, 8, 7988.

Prus B., Antolak M., BartoszczukW., Bernaciak A., Jopek D., Majewska A., Oleński M., Pijanowski J.M., Szumigała P., 2015. Problemy ksztattowania tadu przestrzennego, Kraków, Wydawnictwo Uniwersytetu Rolniczego w Krakowie.

Springer F., 2013. Wanna z kolumnada. Reportaże o polskiej przestrzeni, Wołowiec, Wydawnictwo Czarne.

Ustawa z dnia 24 kwietnia 2015 r. o zmianie niektórych ustaw w związku ze wzmocnieniem narzędzi ochrony krajobrazu (Dz.U. 2015 poz. 774).

Ustawa z dnia 27 marca 2003 r. o planowaniu i zagospodarowaniu przestrzennym (Dz.U. 2003 nr 80 poz. 717).

Ustawa z dnia 16 kwietnia 2004 r. o ochronie przyrody (Dz.U. 2004 nr 92 poz. 880)

Woźniak M., 2015. Ład przestrzenny jako paradygmat zrównoważonego gospodarowania przestrzenią. Biatostockie Studia Prawnicze, 18, 167-182. 


\section{Tutoring Gedanensis}

Notka o Autorze: student pierwszego roku studiów magisterskich na kierunku Geografia społeczno-ekonomiczna z elementami GIS na Uniwersytecie Gdańskim. Interesuje się transportem i gospodarką przestrzenną. W wolnym czasie zajmuje się piłką nożną i czytaniem reportaży. Jego marzenia związane są z podróżami. 